\title{
スイーツセミナー $2-2$
}

\section{SS2-2}

\section{ループス腎炎における免疫抑制剂治療の意義}

北海道大学大学院医学研究科 免疫・代謝内科学分野

保田晋助

ループス腎炎（LN）は，全身性エリテマトーデス患者の予後を規定する主要な臟器病変である，寛解導入 療法においてはさまざまな免疫抑制治療に関するRCT が主に海外で行われ, 多くのエビデンスが得られてきた. シクロホスファミド間欠静注療法（IVCY）の有効性が確立された時期に続いて，その毒性に対する認識の広 がりから low dose IVCY が考案され，またミコフェノール酸モフェチル（MMF）がIVCYに劣らない寛解導 入効果と高い安全性が確認された。近年, 中国からタクロリムス（TAC）が IVCY や MMFに見劣りしない寛 解導入効果を示すことが示されている。 また，MMF と TACの併用療法はIVCY に対して優位性があるものの 有害事象がやや多いとの報告もなされた.

本邦ではミゾリビン，TACに加えて IVCY，アザチオプリンの使用が認可されており，本年 MMFも LNに 対して適応追加された。日本リウマチ学会が行ったLNに対するMMFの使用実態調查では，ステロイド併用 下に打ける有効性と安全性が示され, 約 $1 / 3$ の症例で TAC が併用されていること, 最大投与量は $2 \mathrm{~g} /$ 日程度で あることなどが明らかになった，本邦での LN 治療のおかれた環境は，薬剤選択の面では恵まれているが，ど の薬剤を単剂で, あるいは併用で用いてゆくか, 維持療法への切り替えなど, 今後エビデンスを構築してゆく 必要がある。 